\title{
Some Biological Aspects of Atlantic Wolffish (Anarhichas lupus) in the Northwest Atlantic
}

\author{
Wilfred Templeman \\ Science Branch, Department of Fisheries and Oceans \\ Northwest Atlantic Fisheries Centre, P. O. Box 5667 \\ St. John's, Newfoundland, Canada A1C 5X1
}

\begin{abstract}
Research on sexual maturity, spawning and fecundity of Atlantic wolffish (Anarhichas lupus) in various parts of the Northwest Atlantic, and on the resultant length-weight effects, was carried out incidentally during 1946-67 in conjunction with investigations which were directed toward other demersal species. Sexual maturity in females began at a relatively small size $(43 \mathrm{~cm})$ off Labrador and northeastern Newfoundland, in contrast to a much larger size $(58 \mathrm{~cm})$ in the St. Pierre Bank and southern Grand Bank areas, with the size on the northern Grand Bank $(49 \mathrm{~cm})$ being intermediate. In other areas from the Scotian Shelf to West Greenland, the sizes at first maturity were similar to or smaller than $43 \mathrm{~cm}$. Maximal lengths of wolffish were considerably greater in areas where sexual maturity occurred at larger sizes than in areas where it occurred at much smaller sizes. Trends in weight of ovaries and sizes of eggs throughout the year indicated that spawning was mainly in the autumn. However, a wolffish (apparently A. lupus) egg cluster, with some eggs hatched, was found on the southern Grand Bank in April 1960. Fecundity increased exponentially with fish length, the average number of eggs being 2,440 at $40 \mathrm{~cm}$ and 35,320 at $120 \mathrm{~cm}$. Length-weight relationships (log-log regressions) indicated that average weights by calendar quarter typically ranged from lowest to highest in October-December, January-March, April-June and July-September. The low values in October-December were attributed to fasting and change of teeth which occur during the spawning period, followed by resumption of feeding and consequent increase in weight-at-length to highest values in July-September.
\end{abstract}

\section{Introduction}

The Atlantic wolffish (Anarhichas lupus), being one of two commercially important species of wolffishes in the Northwest Atlantic, is usually caught incidentally in fisheries which are directed to other demersal fishes (see Templeman, 1984a). Previous research on the biology of this species by Barsukov (1953, 1959), Beese and Kändler (1969) and Jónsson (1982), relevant to the subject matter of this paper, was concerned mainly with populations in the North Atlantic from Greenland to the Barents Sea.

Published information on the biology and ecology of $A$. lupus in the Northwest Atlantic is quite limited. Smidt (1981), in a brief description of the wolffish fishery off West Greenland, outlined the problems which were encountered in attempts to provide scientific advice for management of the fishery for $A$. lupus and $A$. minor in that region. Albikovskaya (1982) described the distribution and abundance of $A$. lupus by depth and temperature in the Newfoundland area, and Templeman (1984a) described migrations of the species from tagging in the same region. Keats et al. (1985) observed reproduction and egg guarding by Atlantic wolffish during scuba-diving in coastal waters $(5-15 \mathrm{~m}$ deep) of the eastern Avalon Peninsula, Newfoundland. Templeman (1984b) discussed the meristic variation in $A$. lupus from collections in most areas of the Northwest Atlantic (West Greenland to the Scotian Shelf).
This paper deals with several aspects of the biology of Atlantic wolffish from collections of data throughout much of the Northwest Atlantic but with special emphasis on materials from the LabradorNewfoundland region.

\section{Materials and Methods}

Research on the biology of Atlantic wolffish in the Northwest Atlantic was carried out during 1946-67 with the collection of data and materials during cruises of fishery research vessels of the St. John's Biological Station, the activities of which were directed primarily toward other demersal species. Most of the samples were obtained in the Labrador-Newfoundland region, but some were taken off West Greenland and on the Scotian Shelf (Fig. 1). Fishing was typically by bottom trawl which had a small-mesh liner in the codend. However, in the case of most specimens over $47 \mathrm{~cm}$ long from Flemish Cap (NAFO Div. 3M), approximately half were taken by bottom longline and half by bottom trawl without small-mesh liner. On the Scotian Shelf (Div. $4 \mathrm{VWX})$, about two-thirds of the large wolffish $(>60 \mathrm{~cm})$ were taken by handline at a depth of $40 \mathrm{~m}$ off Port La Tour in Div. 4X. The wolffish, with mouth closed, were measured as greatest total length to the nearest centimeter.

Maturing females were determined by the rela- 


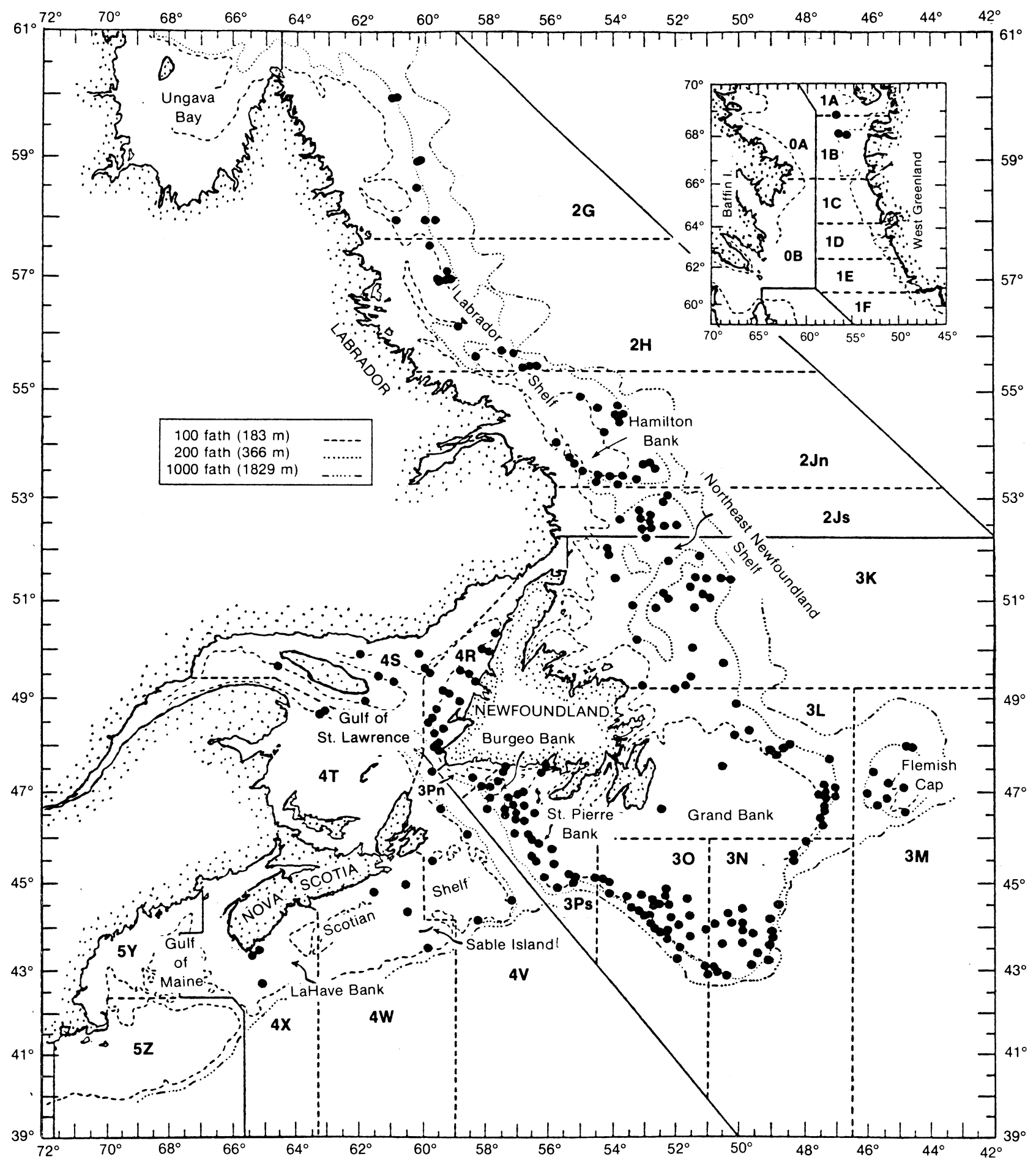

Fig. 1. Place names, NAFO divisions and locations of Atlantic wolffish samples in the Northwest Atlantic.

tively large size of developing eggs ( $>1.5 \mathrm{~mm}$ diameter), which differed in color from the background white of the smaller second generation eggs $(<1.0$ to 1.4 $\mathrm{mm}$ ). Females which had spawned previously, especially the large ones whose eggs for the next spawning had not developed beyond the whitish condition, could usually be recognized as mature by the tough, wrinkled ovarian walls and the presence of residual eggs. Ovaries of doubtful maturity, many of which may have been recovering from first spawning, were checked for maturity by searching for large residual eggs from the previous spawning. Also, the mature category includes, for convenience, some females which were obviously maturing for the first time. 
For fecundity estimation, complete ovaries of Atlantic wolffish with developing eggs were preserved at sea in individual containers with $5 \%$ formalin. Before egg-counting commenced in the laboratory, the ovarian wall, connective tissue and most of the second generation eggs were removed and discarded. The remainder of the ovary, consisting mainly of yellowish developing eggs, was then strained and weighed to the nearest $0.01 \mathrm{~g}$. A fraction, usually $1 / 10$ or $1 / 5$ of the total weight of developing eggs $(1,000-2,000$ by number $)$, was taken at random for weighing and counting. Two samples were counted from approximately every fifth ovary, and the counts of some samples were checked by a supervising technician. Egg counts in five samples (1,009-2,542 eggs) from different ovaries by one technician and recounts by another varied only by $1.02 \%$. The eggs in samples (1/4 to $1 / 2$ of ovary weight) from seven small ovaries were counted, and all remaining eggs were also counted. The estimated total number of eggs based on the sampled portions was $0.27 \%$ higher than the total count of 24,670 eggs.

The weight-length data were obtained in the laboratory from fish which were collected during the last few days of the cruise and frozen or stored in ice. All fish were weighed in the head-on eviscerated condition with all internal body organs and the gills removed. Weights were usually taken to the nearest $50 \mathrm{~g}$, but very large fish $(>13 \mathrm{~kg}$ ) were weighed to the nearest $0.5 \mathrm{~kg}$. Frozen fish were thawed in melting ice before length and weight measurements were taken. Least-squares log-log (base 10) regressions of weight ( $\mathrm{kg}$ to 2 decimal places) on total length $(\mathrm{cm})$ were calculated by sex and calendar quarter for the two sets of grouped data which exhibited different "first sizes" at sexual maturity. Pairs of these regressions were compared by covariance analysis (Snedecor and Cochran, 1980).

\section{Results}

\section{Length frequencies}

The combined length frequencies of Atlantic wolffish in the 1946-67 period for six areas of the Northwest Atlantic, extending from northern Labrador to the southern Grand Bank and then westward to the Gulf of St. Lawrence and the Scotian Shelf (Fig. 1), show considerable variation in modes and length ranges (Fig. 2). The smallest fish were from the Labrador-Northeast Newfoundland Shelf area (Div. $2 \mathrm{GHJ}+3 \mathrm{~K}$ ) and the Gulf of St. Lawrence (Div. 4R), with very similar length frequencies. The largest fish and the broadest range of sizes were found on the southern Newfoundland banks (Div. 3NOPs), with fish from the Scotian Shelf (Div. $4 \mathrm{VWX}$ ) and Flemish Cap (Div. 3M) being next in terms of the larger sizes. However, as noted in "Materials and Methods", the length frequencies for the last two areas

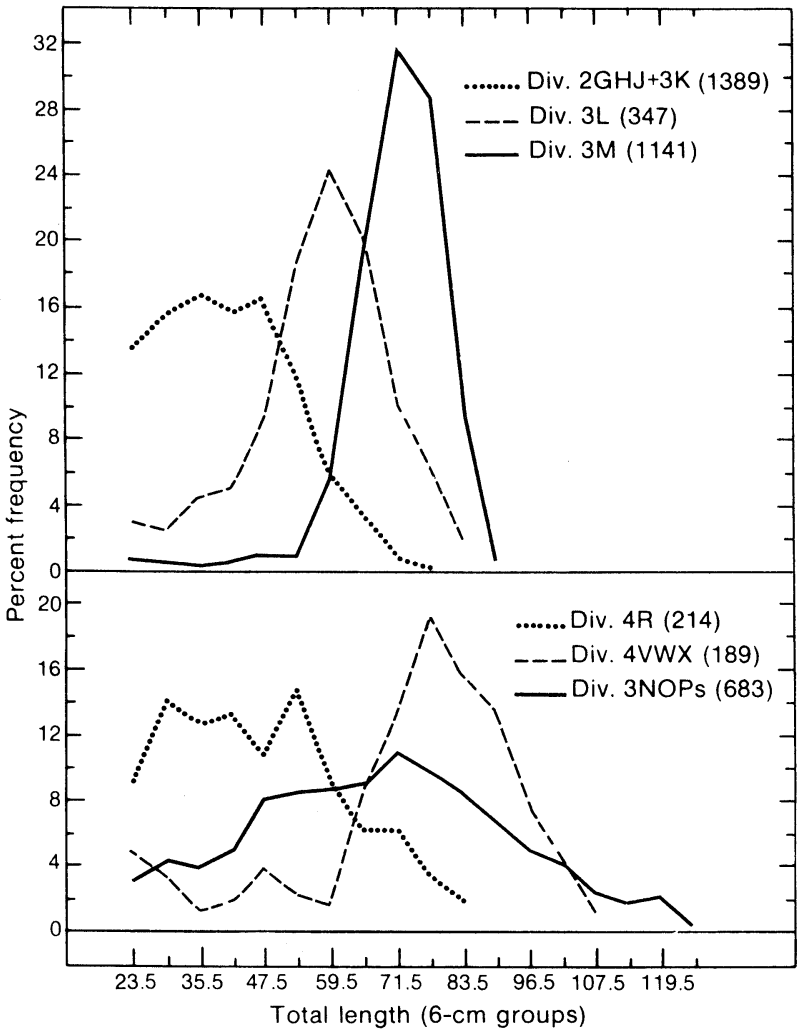

Fig. 2. Length distributions of Atlantic wolffish $(>20 \mathrm{~cm})$ from various areas of the Northwest Atlantic, 1946-67. (Numbers of fish in parentheses.)

are probably biased toward larger size-groups because they include samples that were caught by longline in one case and handline in the other. The fish from the northern Grand Bank (Div. 3L) seemed to be intermediate in size relative to the northern and southern groups. The largest Atlantic wolffish was a $127-\mathrm{cm}$ male $(25.9 \mathrm{~kg}$ round weight and $22.7 \mathrm{~kg}$ eviscerated weight) from Div. 3N on 3 May 1966. The largest female, also from Div. $3 \mathrm{~N}$, was $121 \mathrm{~cm}$ long.

\section{Sexual maturity}

Field observations of sexual maturity in Atlantic wolffish, taken throughout the year, were found to be more accurate for females than for males, and, consequently, the length distributions of immature and mature females were used for comparisons of sizes at sexual maturity by area (Fig. 3). It is evident that maturaton occurred at considerably smaller fish sizes in the northern part of the region (Div. $2 \mathrm{GHJ}+3 \mathrm{~K}$ ) than in the southern area (Div. 3NOPs), and probably at intermediate sizes on the northeastern Grand Bank (Div. 3L). Plots of the proportions of mature females by lengthgroup could be approximated by S-shaped curves (Fig. 4 ), from which the estimated lengths at $50 \%$ maturity were $51.4 \mathrm{~cm}$ for the northern area, $61.0 \mathrm{~cm}$ for the intermediate area, and $68.2 \mathrm{~cm}$ for the southern area. 


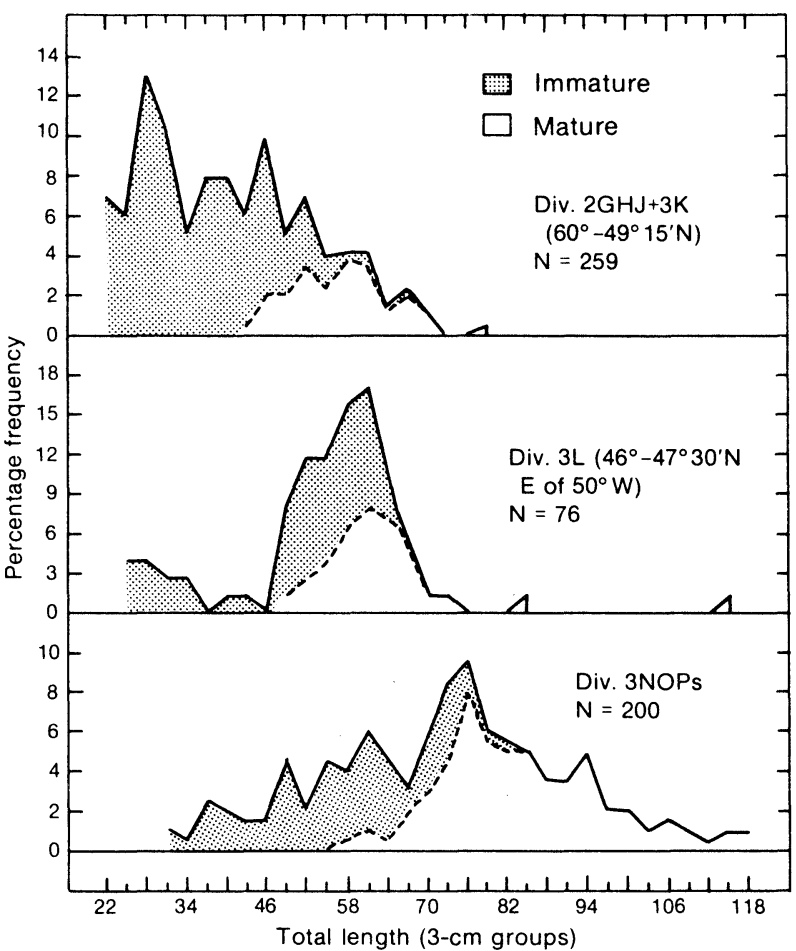

Fig. 3. Length distributions of immature and mature female Atlantic wolffish $(>20 \mathrm{~cm})$ relative to total females from three areas of the Labrador-Newfoundland region, 1946-67. (Numbers of fish are indicated.)

Some maturity data for other areas, being too few to be presented as length frequencies, were compared with those for the three above-mentioned areas in terms of minimum and maximum sizes (Table 1). It is probable that sexual maturity in females in these areas (West Greenland, Flemish Cap, Gulf of St. Lawrence and northeastern Scotian Shelf) first occurred at sizes at least as small as those from Labrador-Northeast Newfoundland Shelf area.

\section{Egg development and spawning}

Egg sizes. Observations on egg sizes were recorded for more than 500 female Atlantic wolffish

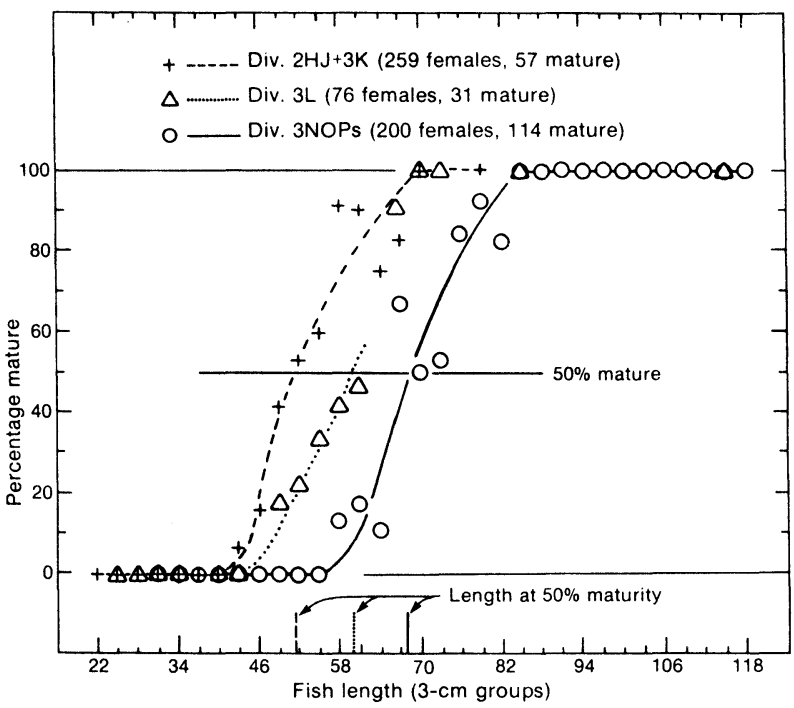

Fig. 4. Length-maturity ogives for female Atlantic wolffish from three areas of the Labrador-Newfoundland region, 1946-67. (Numbers of fish are indicated.)

(303 immature and 218 mature). Eggs were generally not visible to the naked eye in the ovaries of the smallest immatures, but the proportion of ovaries with visible eggs increased rapidly with fish size, as follows:

\begin{tabular}{cccc}
\hline $\begin{array}{c}\text { Length } \\
(\mathrm{cm})\end{array}$ & \multicolumn{3}{c}{ Numbers of eggs } \\
\cline { 2 - 4 } & Not visible & Visible & Total \\
\hline $9-20$ & 24 & 0 & 24 \\
$21-29$ & 22 & 22 & 44 \\
$30-35$ & 2 & 29 & 31 \\
$>35$ & 0 & 204 & 204 \\
Total & 48 & 255 & 303 \\
\hline
\end{tabular}

Visible eggs in the ovaries of 255 immature fish were usually small (Table 2), mainly less than $1.2 \mathrm{~mm}$ diameter, although a few were 1.2-1.4 $\mathrm{mm}$. On the average, smaller immatures had smaller eggs than the larger ones.

Most of the mature fish had small eggs in JanuaryFebruary, but there was a general increase in egg

TABLE 1. Comparative data on maximum length of immature (IMM) and minimum length of mature (MAT) Atlantic wolffish from various areas of the Northwest Atlantic, 1946-67. (Lengths are midpoints of 3-cm length groups.)

\begin{tabular}{|c|c|c|c|c|c|c|c|}
\hline \multirow{2}{*}{$\begin{array}{c}\text { NAFO } \\
\text { Div. }\end{array}$} & \multirow[b]{2}{*}{ General area } & \multicolumn{2}{|c|}{$\begin{array}{c}\text { Number of } \\
\text { females }\end{array}$} & \multirow{2}{*}{$\begin{array}{c}\text { Length } \\
\text { range } \\
(\mathrm{cm})\end{array}$} & \multirow{2}{*}{$\begin{array}{c}\text { Largest } \\
\text { IMM } \\
(\mathrm{cm})\end{array}$} & \multirow{2}{*}{\multicolumn{2}{|c|}{$\begin{array}{l}\text { Smallest } \\
\text { MAT }^{\mathrm{a}} \\
(\mathrm{cm})\end{array}$}} \\
\hline & & IMM & MAT & & & & \\
\hline $2 \mathrm{GHJ}+3 \mathrm{~K}$ & Labrador and NE Nfld shelves & 202 & 56 & $22-79$ & 67 & 43 & $(46)$ \\
\hline $3 \mathrm{~L}$ & $\mathrm{~N}$ Grand Bank ( $\mathrm{E}$ of $50^{\circ} \mathrm{W}$ ) & 43 & 31 & $25-115^{b}$ & 67 & 49 & \\
\hline $3 N O P S$ & S Grand Bank-St. Pierre Bank & 86 & 114 & $22-118$ & 82 & 58 & (61) \\
\hline $1 A B$ & W Greenland (northern areas) & 1 & 2 & $25-58$ & - & 37 & \\
\hline $3 \mathrm{M}$ & Flemish Cap & 13 & 7 & $25-79$ & 64 & 43 & (43) \\
\hline $4 \mathrm{R}$ & W Newfoundland & 31 & 13 & $22-76$ & 61 & 34 & (34) \\
\hline $4 V W$ & NE Scotian Shelf & 3 & 8 & $25-76$ & - & 37 & (37) \\
\hline
\end{tabular}

a Numbers in parentheses are sizes of smallest mature females with residual eggs observed in the ovaries.

b Only one specimen longer than $85 \mathrm{~cm}$ total length. 
TABLE 2. Seasonal frequencies of diameters of largest new eggs in ovaries of immature and mature Atlantic wolffish from the Northwest Atlantic.

\begin{tabular}{|c|c|c|c|c|c|c|}
\hline \multirow{2}{*}{$\begin{array}{c}\text { Egg } \\
\text { diameter } \\
(\mathrm{mm}) \\
\end{array}$} & \multicolumn{6}{|c|}{ Number of wolffish } \\
\hline & $\begin{array}{c}\text { Jan- } \\
\text { Feb }\end{array}$ & $\begin{array}{c}\text { Mar- } \\
\text { Apr }\end{array}$ & $\begin{array}{l}\text { May- } \\
\text { Jun }\end{array}$ & $\begin{array}{l}\text { Jul- } \\
\text { Aug }\end{array}$ & $\begin{array}{c}\text { Sep- } \\
\text { Oct }\end{array}$ & $\begin{array}{l}\text { Nov- } \\
\text { Dec }\end{array}$ \\
\hline \multicolumn{7}{|c|}{ Immature } \\
\hline $0.2-0.4$ & 1 & 17 & 5 & 2 & - & 5 \\
\hline $0.5-0.9$ & 2 & 19 & 26 & 22 & 27 & 45 \\
\hline $1.0-1.1$ & 2 & 8 & 13 & 18 & 20 & 10 \\
\hline $1.2-1.4$ & - & 2 & 3 & 1 & 3 & 4 \\
\hline Total & 5 & 46 & 47 & 43 & 50 & 64 \\
\hline
\end{tabular}

\begin{tabular}{crrrrrr}
\multicolumn{7}{c}{ Mature } \\
$0.6-0.9$ & 3 & 3 & 1 & 1 & 3 & 4 \\
$1.0-1.4$ & 8 & 14 & 11 & 2 & 12 & 1 \\
$1.5-1.9$ & - & 8 & 8 & - & 1 & 2 \\
$2.0-2.4$ & 1 & 7 & 20 & 6 & - & - \\
$2.5-2.9$ & - & 1 & 16 & 4 & 1 & - \\
$3.0-3.4$ & - & 1 & 20 & 18 & 1 & - \\
$3.5-3.9$ & - & 2 & 6 & 17 & 2 & - \\
$4.0-4.4$ & - & - & 2 & 6 & 3 & - \\
$5.0-5.5$ & - & - & - & - & 1 & 1 \\
Total & 12 & 36 & 84 & 54 & 24 & 8 \\
\hline
\end{tabular}

diameter during the ensuing months to July-August (Table 2). There were relatively fewer females with large eggs in September-October, and fish with large developing eggs were not noted in November-December. The single specimen with 5.0-mm eggs in September-October was apparently ready for spawning, and the fish with $5.5 \mathrm{~mm}$ eggs in November-December was partly spent with hundreds of large translucent eggs still present. However, the small numbers of mature females in the autumn samples, especially in November-December, reduce the precision of the results for these months.

The newly-maturing eggs (1.6-4.2 $\mathrm{mm}$ diameter) were generally yellowish in color, whereas the smaller new-generation eggs passed through greyish, whitish and white color stages as they increased in size from "just visible to naked eye" to about $1.4 \mathrm{~mm}$ diameter. The large residual eggs were recorded as being translucent or clear. The whitish, second-generation eggs tended to remain in a resting stage as the yellowish eggs developed for spawning, with further development occurring after spawning had taken place. These whitish eggs were always present in maturing, spent and early-recovering ovaries.

Variation in ovarian weight. Relative to eviscerated weight of the fish, ovarian weight ranged from 0.1 to $1.6 \%$ for immature females and from 0.7 to $28.3 \%$ for mature females (Table 3 ). The immature fish exhibited little variation in weight of ovaries throughout the year. However, the average relative weight of ovaries in mature (and maturing) females increased consistently from $1.3 \%$ in January-February to $9.8 \%$ in July-August,
TABLE 3. Seasonal frequencies of ovarian weight (as percent of eviscerated weight) in immature and mature Atlantic wolffish from the Northwest Atlantic.

\begin{tabular}{lrrrrrr}
\hline \hline $\begin{array}{l}\text { Percent } \\
\text { ovarian } \\
\text { weight }\end{array}$ & $\begin{array}{c}\text { Jan- } \\
\text { Feb }\end{array}$ & $\begin{array}{c}\text { Mar- } \\
\text { Apr }\end{array}$ & $\begin{array}{c}\text { May- } \\
\text { Jun }\end{array}$ & $\begin{array}{c}\text { Jul- } \\
\text { Aug }\end{array}$ & $\begin{array}{c}\text { Sep- } \\
\text { Oct }\end{array}$ & $\begin{array}{r}\text { Nov- } \\
\text { Dec }\end{array}$ \\
\cline { 2 - 7 } & \multicolumn{7}{c}{ Immature } \\
$0.1-0.4$ & 2 & 2 & 26 & 1 & 13 & 33 \\
$0.5-0.9$ & 1 & 12 & 37 & 15 & 29 & 30 \\
$1.0-1.4$ & - & 1 & 2 & 8 & 7 & 2 \\
$1.5-1.6$ & - & - & 1 & 1 & - & 2 \\
Mean (\%) & 0.4 & 0.7 & 0.6 & 0.9 & 0.7 & 0.5
\end{tabular}

\begin{tabular}{rrrrrrr}
$0.7-1.9$ & 10 & 21 & 23 & 3 & 10 & 15 \\
$2.0-3.9$ & - & 6 & 17 & 2 & 2 & 4 \\
$4.0-5.9$ & - & 3 & 17 & 5 & - & - \\
$6.0-7.9$ & - & 1 & 10 & 7 & - & - \\
$8.0-9.9$ & - & - & 6 & 7 & - & - \\
$10.0-11.9$ & - & - & - & 8 & 3 & - \\
$12.0-13.9$ & - & - & - & 12 & 1 & - \\
$14.0-15.9$ & - & - & - & 2 & - & - \\
$16.0-17.9$ & - & - & - & 2 & 1 & - \\
$18.0-20.9$ & - & - & - & 2 & 1 & - \\
$27.0-28.3$ & - & - & - & - & 2 & - \\
Mean $(\%)$ & 1.3 & 2.2 & 3.9 & 9.8 & 7.8 & 1.6 \\
\hline
\end{tabular}

followed by a slight decrease in September-October, and a large reduction in November-December to approximately the January-February level. Examination of the ovarian weights in relation to fish size, for the mature females noted in Table 3, revealed no consistent pattern in any bimonthly period.

Wolffish egg masses and larvae. Bottom-trawling in $100 \mathrm{~m}$ near Sable Island on the Scotian Shelf (19 February 1937) yielded some wolffish egg masses, apparently from $A$. lupus (McKenzie and Homans, 1938). Powles (1967) found Atlantic wolffish eggs to be plentiful at approximately $130 \mathrm{~m}$ over a fairly large area south of LaHave Bank (7-11 March 1966). A cluster of wolffish eggs was found on 27 April 1960 in a bottomtrawl catch of the research vessel A. T. Cameron on the southern Grand Bank ( $\left.44^{\circ} 15^{\prime} \mathrm{N}, 51^{\circ} 36^{\prime} \mathrm{W}\right)$ in $75 \mathrm{~m}$ with bottom temperature of $2.4^{\circ} \mathrm{C}$. This cluster was about $12 \mathrm{~cm}$ in diameter. Some eggs contained welldeveloped embryos, others had hatched, and larvae with large yolk sacs were present in the cluster. These larvae were 17-18 $\mathrm{mm}$ long, after preservation in formalin. They were presumably $A$. lupus, because only Atlantic wolffish were taken during the survey of the southern Grand Bank area where the egg cluster was found.

\section{Fecundity}

Fecundity-length relationships for Atlantic wolffish were calculated by least squares regression of the estimated number of eggs per ovary on total length of 
fish $(\mathrm{cm})$, with both variables transformed to base 10 logarithms. The difference in ranges of fish size prompted calculation of separate regressions for the northern (Div. $2 \mathrm{HJ}+3 \mathrm{~K}$ ) and southern (Div. 3NOPs) parts of the Labrador-Newfoundland region (Table 4), although the number of fecundity estimates for each area was quite small (21 and 16 respectively). Analysis of covariance (Snedecor and Cochran, 1980) showed no significant difference between the regressions, and the data for the two areas were combined, together with seven additional fecundity estimates for the region (5 from Div. 3L, 1 from Div. 3M and 1 from Div. $4 \mathrm{R}$ ), for a total of 44 observations (Table 4 , Fig. 5). The resultant retransformed relationship between fecundity $(F)$ and fish length $(L, c m)$ for Atlantic wolffish in the Labrador-Newfoundland region as a whole is

$$
F=0.3090 L^{2.4329}
$$

The fecundity-length regressions for Atlantic wolffish in the White Sea (Barsukov, 1953) and the West Greenland-Barents Sea region (Beese and Kändler, 1969) appear to have slopes and intercepts which are different from those of the regression for the Labrador-Newfoundland region (Table 4, Fig. 5). However, these three regressions were not compared by analysis of covariance, because the published fecundity estimates were given as mean values for grouped lengths, in contrast to the availability of individual observations for the present study. Also, there is some question as to the representativeness of the combined samples from the West Greenland-Barents Sea region, as a breakdown of the fecundity data for different parts of this wide region was not available.

Individual fecundity estimates for Atlantic wolffish from the Labrador-Newfoundland region ranged from 2,300 eggs in a 44-cm specimen to 37,920 eggs in a $117-\mathrm{cm}$ fish, and mean values at various fish sizes from the fecundity-length relationship ranged from 2,440 eggs at $40 \mathrm{~cm}$ to 35,320 eggs at $120 \mathrm{~cm}$ (Table 4). Mean fecundities, derived by the author from the data of Barsukov (1953) for the White Sea, ranged from 840 eggs at $30 \mathrm{~cm}$ to 5,880 eggs at $60 \mathrm{~cm}$, and mean values from the data of Beese and Kändler (1969) for the West Greenland-Barents Sea region ranged from 2,820 eggs at $40 \mathrm{~cm}$ to 9,770 eggs at $80 \mathrm{~cm}$. Maslov (1944), cited by Barsukov (1959), reported fecundities which ranged from 2,500 eggs at $43 \mathrm{~cm}$ to 23,580 eggs at $81 \mathrm{~cm}$ for $A$. lupus from the Barents Sea, the latter value being considerably higher than that from the Beese and Kändler (1969) data for 80-cm fish. Jónsson (1982) reported from Iceland waters a $25-\mathrm{cm}$ mature female $A$. lupus with 338 eggs in late stage of development, a $26-\mathrm{cm}$ female with 490 well-developed eggs and a $59-\mathrm{cm}$ female in near-spawning condition with 4,900-5,000 eggs. While fecundity estimates for the smallest mature females were from Iceland and White Sea samples and those for the largest fish were from the south-

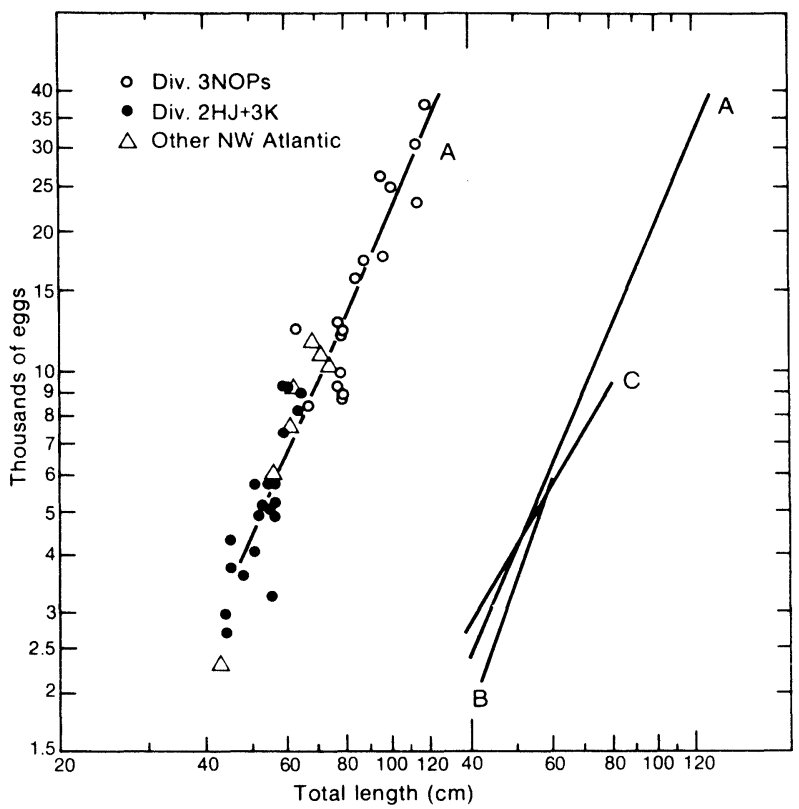

Fig. 5. Fecundity-length relationships for Atlantic wolffish from (A) the Labrador-Newfoundland region, and relative to regression lines for published data from (B) the White Sea (Barsukov, 1953) and (C) the West Greenland-Barents Sea region (Beese and Kändler, 1969).

TABLE 4. Comparative fecundity estimates for Atlantic wolffish, calculated from fecundity-length relationships based on least squares log-log regressions of fecundity on fish length.

\begin{tabular}{|c|c|c|c|c|c|c|c|c|c|c|c|}
\hline \multirow[b]{2}{*}{ Area } & \multicolumn{7}{|c|}{ Fecundity (number of eggs) at fish length $(\mathrm{cm})$} & \multirow{2}{*}{$\begin{array}{l}\text { No. } \\
\text { of } \\
\text { fish }\end{array}$} & \multirow{2}{*}{$\begin{array}{l}\text { Length } \\
\text { range } \\
(\mathrm{cm})\end{array}$} & \multicolumn{2}{|c|}{$\begin{array}{c}\text { Parameters of } \\
\text { log-log regression }\end{array}$} \\
\hline & 30 & 40 & 50 & 60 & 80 & 100 & $\overline{120}$ & & & Slope & Intercept \\
\hline White Sea ${ }^{a}$ & 840 & 1,880 & 3,520 & 5,880 & - & - & - & 85 & $30-64$ & 2.8134 & -1.2336 \\
\hline $\begin{array}{l}\text { Barents Sea to } \\
\text { West Greenland }\end{array}$ & - & 2,820 & 4,210 & 5,830 & 9,770 & - & - & 28 & $\sim 44-85$ & 1.7915 & 0.5804 \\
\hline Div. $2 H J+3 K(A)$ & - & 2,520 & 4,200 & 6,380 & 12,300 & - & - & 21 & $45-79$ & 2.2847 & -0.2582 \\
\hline Div. 3NOPs (B) & - & - & - & 6,830 & 13,230 & 22,100 & 33,600 & 16 & $63-117$ & 2.2995 & -0.2547 \\
\hline Combined $(A+B)^{c}$ & - & 2,440 & 4,200 & 6,550 & 13,180 & 22,680 & 35,320 & 44 & $44-117$ & 2.4329 & -0.5101 \\
\hline
\end{tabular}

a Data from Barsukov (1953), assuming his ranges (30-35-40 cm, etc.) to be 30-34 (mean 32), 35-39 (mean 37), etc.

${ }^{b}$ Data from Beese and Kändler (1969)

${ }^{\circ}$ Combined data also includes 5 fish from Div. 3L, 1 from Div. 3M, and 1 from Div. 4R. 
ern part of the Newfoundland area (Grand Bank and St. Pierre Bank), most of the estimates for various areas of the North Atlantic were not greatly different at comparable fish lengths.

The fecundity counts were derived from ovaries in which the average diameter of developing eggs ranged from 1.8 to $4.2 \mathrm{~mm}$. There was the possibility that the egg counts were low, because some of the small whitish eggs, usually about $1.2 \mathrm{~mm}$ diameter, may also have been developing for spawning. The likelihood of this occurrence would be expected to be greater in the ovaries with smaller developing eggs than in those with larger eggs. In order to check this, the estimated number of eggs in each of 44 ovaries was expressed as a percentage of the average fecundity for the corresponding fish length from the fecundity-length relationship for the Labrador-Newfoundland region. From a plot of these percentages against mean diameters of eggs, the linear regression had a slightly negative slope, but there was no indication that the relative egg counts were lower in ovaries with smaller eggs than in those with larger eggs.

\section{Weight-length}

Preliminary plots of eviscerated (gutted and gilled) weight $(\mathrm{kg})$ against length $(\mathrm{cm})$ by sex, area and quarterly period showed that the weight-length relationships of Atlantic wolffish could be represented closely by log-log least-squares regressions, the correlation coefficients of which ranged from 0.97 to 0.99 (Table 5 ). Eviscerated weights were used because they were more reflective of fish condition than whole weights which may vary with gonad development and feeding intensity. The weight of gills was $2.68 \%$ of the head-on gutted weight (including gills) in 175 Atlantic wolffish with length range of $30-124 \mathrm{~cm}$.

Sexual differences. In five of the six pairs of malefemale weight-length relationships for the two areas where first maturity occurred at smaller and larger sizes (Table 5A), males and females were not distinctly different at $40 \mathrm{~cm}$ but males weighed more than females at each of 60,80 and $100 \mathrm{~cm}$. The exception was the October-December period in Div. 3NOPs, with females being heavier than males at the larger sizes. Statistically, however, a significant difference was evident only in the slopes of one male-female pair, and, for five pairs with non-significant slopes, the intercepts were significantly different in two cases. The variances of all male-female pairs except that for Div. 3NOPs in October-December were homogeneous.

Seasonal differences. Because the differences in the parameters of the male-female regressions were not statistically significant in most cases, data for males and females were combined in the weight-length regressions for seasonal comparisons (Table 5B), the variances of which were homogeneous for all pairs. In Div. 2G-4W, weights of the larger fish were lowest in October-December, intermediate in April-June, and highest in July-September. The slopes of the regressions for the April-June and July-September periods were each highly significantly different $(P<0.01)$ from

TABLE 5. Parameters of log-log regressions of eviscerated weight $(\mathrm{kg})$ and total length ( $\mathrm{cm}$ ) for male (M) and female (F) Atlantic wolffish by quarter and area, and calculated weights $(\mathrm{kg})$ for selected lengths $(\mathrm{cm})$ from the weight-length relationships. ( $r$ is the correlation coefficient.)

\begin{tabular}{|c|c|c|c|c|c|c|c|c|c|c|c|c|}
\hline & \multirow[b]{2}{*}{ Area } & \multirow[b]{2}{*}{ Quarter } & \multirow[b]{2}{*}{ Sex } & \multirow{2}{*}{$\begin{array}{c}\text { No. } \\
\text { of } \\
\text { fish }\end{array}$} & \multirow{2}{*}{$\begin{array}{c}\text { Length } \\
\text { range } \\
(\mathrm{cm})\end{array}$} & \multicolumn{2}{|c|}{$\begin{array}{c}\text { Log-log regression } \\
\text { parameters } \\
\end{array}$} & \multirow[b]{2}{*}{$r$} & \multicolumn{4}{|c|}{$\begin{array}{l}\text { Calculated weights }(\mathrm{kg}) \text { for } \\
\text { selected lengths }(\mathrm{cm})\end{array}$} \\
\hline & & & & & & Slope & Intercept & & 40 & 60 & 80 & 100 \\
\hline \multirow[t]{12}{*}{ A. } & $2 G-4 W^{b}$ & Apr-Jun & $M$ & 35 & $32-97$ & 3.2506 & -5.5578 & 0.99 & 0.45 & 1.67 & 4.25 & 8.78 \\
\hline & & & $\mathrm{F}$ & 24 & $30-79$ & 3.0287 & -5.1907 & 0.99 & 0.46 & 1.57 & 3.74 & 7.36 \\
\hline & & Jul-Sep & $M$ & 69 & $46-77$ & 3.1946 & -5.3955 & 0.97 & 0.53 & 1.93 & 4.83 & 9.86 \\
\hline & & & $\mathrm{F}$ & 57 & $30-83$ & 3.1749 & لـ.5857- & 0.98 & 0.50 & 1.82 & 4.53 & 9.21 \\
\hline & & Oct-Dec & $M$ & 49 & $32-94$ & 2.9463 & -5.00677 & 0.99 & 0.52 & 1.71 & 3.99 & 7.69 \\
\hline & & & $F$ & 49 & $33-77$ & 2.8070 & $-4.7885\rfloor$ & 0.99 & 0.51 & 1.60 & 3.58 & 6.69 \\
\hline & 3 NOPS & Jan-Mar & $M$ & 20 & $37-94$ & 3.1595 & -5.4068 & 0.99 & 0.45 & 1.63 & 4.04 & 8.17 \\
\hline & & & $\mathrm{F}$ & 17 & $61-102$ & 2.9287 & -5.0087 & 0.98 & 0.48 & 1.58 & 3.67 & 7.06 \\
\hline & & Apr-Jun & $M$ & 102 & $51-127$ & 3.1144 & -5.3074 & 0.99 & 0.48 & 1.70 & 4.17 & 8.35 \\
\hline & & & $F$ & 77 & $40-118$ & 3.0846 & -5.2594 & 0.99 & 0.48 & 1.69 & 4.11 & 8.18 \\
\hline & & Oct-Dec & $M$ & 53 & $31-91$ & $\left.{ }^{2.7983}\right]$ & -4.7663 & 0.98 & 0.52 & 1.62 & 3.62 & 6.77 \\
\hline & & & $\mathrm{F}$ & 47 & $32-82$ & 3.0394 & -5.1860 & 0.99 & 0.48 & 1.65 & 3.97 & 7.81 \\
\hline \multirow[t]{6}{*}{ B. } & $2 \mathrm{G}-4 \mathrm{~W}$ & Apr-Jun & $M+F$ & 59 & $30-97$ & 3.17217 & $-5.4213\rceil$ & 0.99 & 0.46 & 1.66 & 4.13 & 8.37 \\
\hline & & Jul-Sep & $M+F$ & 126 & $30-83$ & * 3.2211 & ** & 0.98 & 0.51 & 1.88 & 4.75 & 9.75 \\
\hline & & Oct-Dec & $M+F$ & 98 & $32-94$ & ـ & -4.9300 & 0.99 & 0.51 & 1.65 & 3.81 & 7.26 \\
\hline & $3 N O P S$ & Jan-Mar & $M+F$ & 37 & $37-102$ & 3.0571 & -5.23487 & C.99 & 0.46 & 1.59 & 3.83 & 7.58 \\
\hline & & Apr-Jun & $M+F$ & 179 & $40-127$ & $3.1061 \mathrm{~J}$ & لـ.2939- & 0.99 & 0.48 & 1.70 & 4.14 & 8.29 \\
\hline & & Oct-Dec & $M+F$ & 100 & $31-91$ & لـ2.9183 & -4.9743 & 0.99 & 0.50 & 1.64 & 3.80 & 7.28 \\
\hline
\end{tabular}

\footnotetext{
a Analysis of covariance gave significant difference between pairs of regression parameters where * indicates $P<0.05$ and $* \star$ indicates $\mathrm{P}<0.01$; intercepts were not compared statistically when slopes were significantly different.

b Labrador, eastern Newfoundland and Scotian Shelf (Div. 2GHJ+3KLM+4VW).
} 
the slope for the October-December period. For the pair with non-significant slopes, the intercepts differed significantly $(P<0.01)$. In Div. 3NOPs, weights of the larger fish were highest in April-June (there were no data for July-September), lowest in October-December, and intermediate in January-March (Table 5B). The slopes for the April-June and October-December regressions and the intercepts for the JanuaryMarch and April-June regressions were highly significantly different $(P<0.01)$.

\section{Discussion}

\section{Sexual maturity}

Data in this paper show that sexual maturity in female Atlantic wolffish occurs at smaller sizes in the cooler waters of the Labrador-Northwest Newfoundland area than in the warmer waters of southern Grand Bank and St. Pierre Bank. The effect of water temperature on sexual maturity is probably similar in the Northeast Atlantic, where minimal lengths of mature $A$. lupus females were reported to be $30 \mathrm{~cm}$ in the White Sea, $41 \mathrm{~cm}$ in the Barents Sea and about $50 \mathrm{~cm}$ in the North Sea (Barsukov, 1959).

A similar sexual maturity pattern, beginning with smaller sizes of fish off Labrador and northeastern Newfoundland than on the southern Grand Bank and St. Pierre Bank, was demonstrated for Atlantic cod (Gadus morhua) by Fleming (1960) and for thorny skate (Raja radiata) by Templeman (1982). The difference in size at first maturity for Atlantic wolffish in the region, as for cod, was probably due mainly to slower growth in the lower temperatures of the northern areas. Other factors may also play a role, such as those which are responsible for causing the age at maturity of cod to be lower off Labrador than on the southern Grand Bank (Fleming, 1960). However, this pattern is not consistent for Atlantic wolffish, because first maturity evidently begins at the same or even smaller sizes in other Northwest Atlantic areas (e.g. Gulf of St. Lawrence, northeastern Scotian Shelf and Flemish Cap) where the water is warmer than in the Labrador area. Similarly, mature females as small as $25 \mathrm{~cm}$ have been reported from the warmer Icelandic waters (Jónsson, 1982). The occurrences of mature $A$. lupus at smaller sizes in warmer than in colder areas are unlikely to have been due to slower growth at premature sizes in the warmer water. Consequently, some other factors must be responsible for determining the size at maturity in these comparatively warm water areas.

\section{Maximal lengths}

In the Labrador-Newfoundland region, the maximal length attained by Atlantic wolffish seems to be related to the size at the beginning of sexual maturity, with the smallest maximal sizes occurring off Labrador and northeastern Newfoundland where maturity begins at small sizes, and the largest maximal sizes occurring on the southern Grand Bank where maturity begins at considerably greater lengths. Similar variations in maximal sizes of Atlantic cod and thorny skate in the same region have been discussed by Fleming (1960) and Templeman (1982), and it is likely that the main causes and effects of these variations are similar for Atlantic wolffish. The occurrence of small size at first maturity and small maximal size was also evident in wolffish from the Gulf of St. Lawrence (Div. 4R) and possibly also in fish from Flemish Cap (Div. 3M), although the length frequency for the latter area was probably biased by larger fish which were taken mainly by bottom longline and by bottom trawl with largemesh codend. The wolffish from the Scotian Shelf (Div. 4VWX) evidently attained sizes larger than those in areas where maturity at small sizes was prevalent but not quite as large as those on southern Grand Bank and St. Pierre Bank. Sexual maturity apparently occurred at small fish sizes on the northeastern part of the Scotian Shelf, but there were no data on sexual maturity for the western part of Div. $4 \mathrm{~W}$ and the more temperate waters of Div. $4 \mathrm{X}$.

The lower maximal sizes of Atlantic wolffish in areas where sexual maturity occurs at smaller sizes are related to the slowing of growth after maturity, a common phenomenon in fishes. Thus, the greatest length attained in an area has some relation to the size at which maturity occurs and the rate of growth. The largest $A$. lupus in the present Northwest Atlantic data were a $127-\mathrm{cm}$ male and a $121-\mathrm{cm}$ female from the southeastern Grand Bank (Div. $3 N$ ). In reports from other areas of the North Atlantic, maximum sizes of $A$. lupus were $82 \mathrm{~cm}$ in 350 specimens from West Greenland and $83 \mathrm{~cm}$ in 36 fish from East Greenland (Kotthaus and Krefft, 1957), $116 \mathrm{~cm}$ in Icelandic waters (Jónsson, 1982), $116 \mathrm{~cm}$ in Swedish waters (Malm, 1877; cited by Barsukov, 1959), and $115 \mathrm{~cm}$ in the Barents Sea (Barsukov, 1959).

\section{Spawning period}

According to Barsukov (1959), spawning of $A$. lupus in the White Sea in 1951 occurred mainly in July and the first half of August. Spawning of this species off Iceland occurs chiefly in September-October (peak in October), with a small amount in November-December (Jónsson, 1982). The Northwest Atlantic data indicate that spawning occurs mainly in the autumn, but sampling of mature fish was not intensive during the latter part of the year. Some eggs had reached their largest size (before clearing) as early as May-June, and it would not be surprising if some individuals spawned before September.

Keats et al. (1985), by scuba-diving in coastal waters along the eastern Avalon Peninsula, Newfoundland, found male and female Atlantic wolffish pairing 
during the summer and spawning in spaces under and between boulders during the autumn. It was common to find pairs in nesting spaces by August, and spawning occurred from late August to October. No pairs were noted after October. Well-developed embryos were common from mid-September to late November, but egg masses were not noted during observations in early December.

The occurrence of a wolffish (presumably $A$. lupus) egg cluster, with developing embryos, on the southern Grand Bank in April indicates that wolffish eggs in the area may have a long developmental period.

\section{Wolffish condition and spawning}

Keats et al. (1985), from observations on pairs of Atlantic wolffish in nesting sites in coastal waters of the eastern Avalon Peninsula, southeastern Newfoundland, during August-November, noted that females fed very little and males fed moderately well during the prespawning period. After spawning, females resumed feeding, but males fed very little during their guarding of the eggs and resumed feeding only after the eggs had hatched.

Atlantic wolffish lose their teeth and develop new ones yearly close to the time of spawning (Lühmann, 1951, 1954; Barsukov, 1961; Jōnsson, 1982). Off Iceland, the exchange of teeth occurs during or just after spawning in September-October, with the females preceding the males. The toothless period, reinforced by the spawning period, represents a time of fasting when the wolffish change from a well-nourished to an emaciated condition (Jónsson, 1982). To this reduction in feeding activity may be ascribed the occurrence of the lowest average weights in October-December (spawning and postspawning periods), followed by a slow recovery in condition as feeding resumes, with the attainment of the greatest weights and best condition in July-September. The testes are relatively very small in mature wolffish, their maximum weight being only about $1.3 \%$ of the maximum weight of the ovary in fish of the same size (Keatset al., 1985). Consequently, the additional diversion of energy for the development of eggs may, at least in part, account for the apparent, but not significant, weight advantage of the males over the females in the Labrador-Newfoundland region.

\section{References}

ALBIKOVSKAYA, L. K. 1982. Distribution and abundance of Atlantic wolffish, spotted wolffish and northern wolffish in the Newfoundland area. NAFO Sci. Coun. Studies, 3 : 29-32.
BARSUKOV, V. V. 1953. On the biology of reproduction of the White Sea wolffish (Anarhichas lupus L.). Zool. Zh., 32: 1211-1216. (Fish. Res. Board Can. Transl. Ser., No. 1811, 1956.)

1959. The wolffish (Anarhichadidae). Tr. Zool. Inst. Acad. Sci. USSR: Fishes, 5(5), 173 p. (Transl. for Smithsonian Institute and National Science Foundation, Washington, D. C., by Indian National Scientific Doc. Centre, New Delhi, 1972.)

1961. On the time of teeth changing in Atlantic Anarhichadidae. Zool. Zh. 40: 462-465. (Russian with English summary.)

BEESE, G., and R. KÄNDLER. 1969. Beiträge zur biologie der drei nordatlantischen Katfischarten, Anarhichas lupus L., A. minor Olafs. und A. denticulatus Krøyer. Ber. Dtsch. Wiss. Komm. Meeresforsch., 20: 21-59. (Fish. Res. Board Can. Transl. Ser., No. 1811, 1971.)

FLEMING, A. M. 1960. Age, growth and sexual maturity of cod (Gadus morhua L.) in the Newfoundland area, 1947-1950. J. Fish. Res. Board Can., 17: 775-809.

JÓNSSON, G. 1982. Contribution to the biology of catfish (Anarhichas lupus) at Iceland. Rit Fiskideild., 6(4): 3-26.

KEATS, D. W., G. R. SOUTH, and D. H. STEELE. 1985. Reproduction and egg guarding by Atlantic wolffish (Anarhichas lupus, Anarhichidae) and ocean pout (Macrozoarces americanus, Zoarcidae) in Newfoundland waters. Can. J. Zool., 63: 2565-2568.

KOTTHAUS, A., and G. KREFFT. 1957. Fischfaunenliste der Fahrten mit F. F. S. Anton Dohrn nach Island-Grönland. Ber. Dtsch Wiss. Komm. Meeresforsch., 14: 169-191.

LÜHMANN, M. 1951. Gebiss und Zahnwechsel der Katfische. Verh. Anat. Ges. Ergänzungsheft zum 97 Bd. (1950): 241242.

1954. Die histogenetischen Grundlagen des periodischen Zahnwechsels Katfische and Wasserkatzen (Anarhichadidae, Teleostei). Zeitschr. Zellforsch., 40: 470-509

MALM, A. W. 1877. Göteborgs och Bohusläns fauna. Rygradsjuren, Göteborg, Sweden, $674 \mathrm{p}$.

MASLOV, N. A. 1944. The bottom food-fishes of the Barents Sea. Trudy PINRO, Murmansk, 8: 3-186.

McKENZIE, R. A., and R. E. S. HOMANS. 1938. Rare and interesting fishes and salps in the Bay of Fundy and off Nova Scotia. Proc. N. S. Inst. Sci., 19: 277-281.

POWLES, P. M. 1967. Atlantic wolffish (Anarhichas lupus L.) eggs off southern Nova Scotia. J. Fish Res. Board Can., 24: 207-208.

SMIDT, E. 1981. The wolffish fishery at West Greenland. NAFO Sci. Coun. Studies, 1: 35-39.

SNEDECOR, G. W., and W. G. COCHRAN. 1980. Statistical methods (7th edition), lowa State Univ. Press, Ames, lowa, $507 \mathrm{p}$.

TEMPLEMAN, W. 1982. Development, occurrence and characteristics of egg capsules of the thorny skate, Raja radiata, in the Northwest Atlantic. J. Northw. Atl. Fish. Sci., 3 47-56.

1984a. Migrations of wolffishes, Anarhichas sp., from tagging in the Newfoundland area. J. Northw. Atl. Fish. Sci., 5: 93-97.

1984b. Vertebral and dorsal fin-ray numbers in Atlantic wolffish (Anarhichas lupus) of the Northwest Atlantic. J. Northw. Atl. Fish. Sci., 5: 207-212. 
